\title{
Impact of Transformational Leadership on Innovation Characteristic of Enforcement Employees in Malaysian Public Sector Agency. The Role of Trust as Mediator
}

\section{${ }^{1}$ Mohd Hamran Mohamad, ${ }^{2}$ Khulida Kirana Yahya and ${ }^{1}$ Kamarulzaman Lamin}

${ }^{1}$ Faculty of Defence Studies \& Management, National Defence University of Malaysia, Sungai Besi Camp, 57000 Kuala Lumpur, Malaysia. ${ }^{2}$ School of Business Management, College of Business, Universiti Utara Malaysia, 06000, UUM Sintok, Kedah, Malaysia.

Correspondence Author: Mohd Hamran Mohamad, Faculty of Defence Studies \& Management, National Defence University of Malaysia, Sungai Besi Camp, 57000 Kuala Lumpur, Malaysia.

Tel: +6019-9142393; E-mail: hamran@upnm.edu.my

Received date: 12 January 2018, Accepted date: 10 March 2018, Online date: 20 March 2018

Copyright: (c) 2018 Mohd Hamran Mohamad et al. This is an open-access article distributed under the terms of the Creative Commons Attribution License, which permits unrestricted use, distribution, and reproduction in any medium, provided the original author and source are credited.

\begin{abstract}
This study examines the influence of transformational leadership on innovation and investigates whether employees' trust mediates the relationship between transformational leadership and the innovation characteristic of enforcement employees in Malaysia. Less study of transformational leadership, employees' trust and innovation has been conducted at the enforcement agency in Malaysia. Less employees' trust to their organizations has been the obstacle to boost the innovation culture among them. Data on transformational leadership, employees' trust, and innovation characteristic are collected through a survey of Malaysian enforcement body. Analyses are based on Structural Equation Modelling (SEM) technique through AMOS 20. The instruments used in this study have the acceptable validity and reliability. The results of SEM analyses show that transformational leadership has significant effect on innovation and trust. Trust also has significant effect on innovation and mediates the relationship between transformational leadership and innovation. The results are expected to encourage leaders of Malaysian enforcement agencies to guide and motivate their followers through transformational leadership based style. The discussions and implications from the findings of this study are provided to contribute to the literature mainly based on the empirical evidence of the significant relationship between transformational leadership and innovation as well as the role of trust as mediator in the Malaysian enforcement body context.
\end{abstract}

Key words: Transformational Leadership; Innovation and Trust

\section{INTRODUCTION}

Innovation plays important role for the organization sustainability because it is the main factor that portrays the organizational competitiveness, strength and stability from the eyes of its stakeholders. This could be succeeded through innovative employees who create and apply new meaningful idea in upgrading the systems, policies and procedures, and process of organization that make the efficient production and service delivery [1]. Thus, research in the area of innovation should be conducted actively based on individual context since previously, many studies have focused on general team and organizational context [2-4]. For this study, innovation refers to individual level of analysis. This is because innovation is one of the characteristics of individual performance which must be practiced by each employee to provide quality of service delivery mainly in the public sector organizations. Innovation is part of Malaysian government agenda in managing red tape procedures problem, slow work process and importantly, to fight misconducts among the civil servants [5-6] including individuals working as enforcement personnel. Hence, quality of Malaysian public management should be driven by innovative enforcement personnel.

Innovation is defined as the complete implementation of creative ideas (the generation of novel and useful ideas) within an organization [7]. Meanwhile, Belliveau et al 1991 [8] explained innovation as "a new idea, method, or device. The act of creating a new product or process. The act includes invention as well as the work required to bring an idea or concept into final form". Therefore, employees who have creative ideas and innovative actions are able to realize the goals and will bring to the organizational excellence. Researches in this field found the employees who act innovatively may have been influenced by the good leaders who practiced transformational based style [9] mainly in the world of globalization. Most of the organizations need to perform dynamically which urged them to make changes of transactional based leadership to another leadership style namely transformational leadership. Actually, transformational leadership is related to individualized considerations (i.e., leaders realize on followers wants as well as train them to perform better), intellectual stimulations (i.e., leaders emphasize followers' innovation and creativity in succeeding their tasks, as well as require followers to use their own approaches of doing works), inspirational motivations (i.e., leaders determine correct future organizational goals and personal goals of the followers), and idealized influence (i.e., leaders who are very determined, persistent and frequently stress on attainment of their mission, as well as take individual responsibility and demonstrate high moral standards and behavior in generating trust from their followers) [10-11]. The utilizing of relational contract of transformational leadership that is different to economic contract shows the emphasizing of the social exchange (followers respect to their leaders and able to do beyond the scope of formal job contracts), covenant (agreed commitment to the welfare of both parties to the exchange) and psychological contract, that is a set of beliefs held by a person regarding the terms of the exchange agreement to which that person is a party [12].

In an innovation study area, it is found that an association of transformational leadership style with innovation of employees has been discussed, but the mechanism of leadership style influence innovation of the employees is less debated in the direct relationship based research [13-15]. Interestingly, through extra surveys on such relationship, it is found that the impact of transformational leadership on innovation is indirectly affected by employees' trust [16-17]. Trust is explained according to various constructs either individual or organization [18] such as fairness, confidence and risk taking [19]. Therefore, many definitions of trust such as expectation and belief are fundamentally built by construct of confidence, willingness to be vulnerable could be based on risk taking whereas 
Citation: Mohd Hamran Mohamad, Khulida Kirana Yahya and Kamarulzaman Lamin, 2018. Impact of Transformational Leadership on Innovation Characteristic of Enforcement Employees in Malaysian Public Sector Agency. The Role of Trust as Mediator. Advances in Natural and Applied Sciences., 12(3): 60-65.

dependency on another is about fairness, benevolence, ability and other organizational characteristics [20]. According to the leadership research model, employees' trust in organization is possibly affected by transformational behaviors of the leaders (i.e., idealized influence, inspirational motivation and individualized consideration).

Literature Study:

Relationship between Transformational Leadership, Trust and Innovation:

A study performed a direct effect framework to evaluate transformational leadership based on a sample of 175 faculty members from Islamic Azad University in Iran. This study found that the leaders who display transformational style in their jobs (i.e., make followers clear of organizational missions and practice an adaptability) had influenced members of university's faculties to be innovative [15]. Their study matched to the organizational leadership theory. It stated that fairness, the ability including emphasizing clarity and easier to adapt with others, and benevolence of leaders in decision making may drive to positive consequent attitudinal and behavioral outcomes $[10,12]$. This theory could be related to the leadership model that clarifies the leaders who properly use transformational behaviors in planning and administering jobs (e.g., clarity of policy and work process, communication openness, participation, and empowerment) will strongly motivate followers to be more innovative. In supporting their study and parallel to the organizational leadership theory, a study by Sarros, Cooper and Santora [21] also mentioned that transformational leadership style has a significant positive relationship with innovation of members in organization.

Basically, transformational leadership style is able to lead followers' trust mainly their trust in leaders. This could motivate the followers to act with positive attitudes and behaviors. All these relationships have been significantly found from the model of trust initiated by the study of Mayer $e$ t al. [17]. Therefore, it can be interpreted from this model that innovation is appeared through the positive attitudes and behaviors of the followers when they trust and believe the leadership style of their leaders are based on the trustworthiness characteristics such as ability, benevolence and leaders' integrity [17]. For example, transformational leaders performed their integrity based on justice approach by treating followers fairly which equitable outcomes provided to the followers based on their contributions such as equity rule (recognize contribution), needs rule (promote personal welfare) and equality rule (preserve social harmony) [22]. As a result, it affects the followers' trust [23] and subsequently, contributes to positive attitudinal and behavioral outcomes [24] that may portray followers' innovation. The literature is underpinned in developing a conceptual framework for this study as shown in Figure 1 and also the hypotheses as mentioned below.

Independent Variable

Mediating Variable

Dependent Variable

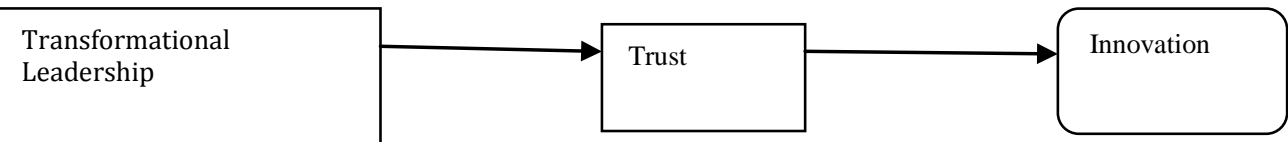

Fig. 1: Conceptual Framework

The hypotheses:

H1: There is a significant relationship between transformational leadership and innovation

H2: There is a significant relationship between transformational leadership and trust

H3: There is a significant relationship between trust and innovation

H4: Trust mediates the relationship between transformational leadership and innovation

Methodology:

This study was designed to test the effect of transformational leadership on employees' innovation in the enforcement based organization of Malaysia in central area. According to the official information from the human resource management of particular organizations, there are more than eight thousand of enforcement employees working in the local authorities (LAs) located in the central region of peninsular Malaysia. This means that the population of this study was more than eight thousands. Therefore, following the recommendation of Krejcie and Morgan [25] and suggestion of Sekaran and Bougie [26], about 600 questionnaires were distributed to the respondents to ensure the representation of sample size. Data was collected from enforcement employees who work in Malaysian local authorities (LAs). The proportionate stratified sampling method was employed in order to ensure the randomness of data collection.

The measurement scales of constructs were taken from previous researches. Particularly, 20 items were taken from the study of Bass and Avolio [11] to measure transformational leadership. To measure employees' innovation based on their transparent ideas and efficient performance, 10 items were taken from Tsui et al. [27] and Rogers [28] to ensure they are fit to the context of the present study. Meanwhile, employees' trust is measured by 12 items adopted from Cook and Wall [29]. All of the designed measurements were measured on a five-Point Likert scale ranging from strongly disagree (1) to strongly agree (5).

For the analyses mainly the investigations of the relationship between the constructs in the model, this study used Structural Equation Modelling (SEM) method through AMOS 20. Using SEM, the goodness of model fit of measurement model is required because it indicates the appropriateness of the selected items of each construct [30]. For this requirement, the confirmatory factor analysis (CFA) was performed for generating an acceptable model fit by determining the correct items based on modification indices output produced by AMOS [31].

Analyses and Results:

Table 1 presents the respondent profile of this study. Respondents were mostly males (52 percent), majority of their ages are between 25 to 33 years old (51.3 percent), Malay respondent represents the biggest percentage (96.7 percent), mostly are SPM holders (54.3 percent), most of the respondents are from municipal council employees (42.7 percent), and working experienced 6 - 10 years (33.7 percent).

Table 1: Participants' Characteristics ( $\mathrm{N}=300)$

\begin{tabular}{llll}
\hline Demographic & Characteristics & Frequency & Percentage \\
\hline Gender & Male & 156 & 52.0 \\
& Female & 144 & 48.0 \\
\hline Age & Less than 25 years & 29 & 9.7 \\
& Between 25 and 35 years & 154 & 51.3 \\
& Between 36 and 45 years & 62 & 20.7 \\
\hline Race & 46 years and above & 55 & 18.3 \\
& Malay & 290 & 96.7 \\
& Chinese & 1 & 0.3 \\
\hline Religion & Indian & 7 & 2.3 \\
& Others & 2 & 0.7 \\
& Islam & 293 & 97.7 \\
& Buddhist & 0 & 0.0 \\
\hline Highest & Hindu & 6 & 2.0 \\
Academic Qualification & Christian & 1 & 0.3 \\
\hline
\end{tabular}


Citation: Mohd Hamran Mohamad, Khulida Kirana Yahya and Kamarulzaman Lamin, 2018. Impact of Transformational Leadership on Innovation Characteristic of Enforcement Employees in Malaysian Public Sector Agency. The Role of Trust as Mediator. Advances in Natural and Applied Sciences., 12(3): 60-65.

\begin{tabular}{llll} 
& SPM & 163 & 54.3 \\
& STPM & 25 & 8.3 \\
& Diploma & 71 & 23.7 \\
\hline Employer & Others & 31 & 10.3 \\
& City Hall/ City Council & 120 & 40.0 \\
& Municipal Council & 128 & 42.7 \\
& District Council & 43 & 14.3 \\
\hline Length of Service & Putrajaya Corporation & 9 & 3.0 \\
& $6-10$ years & 101 & 33.7 \\
& $11-15$ years & 58 & 19.3 \\
\hline Note: & 16 - 20 years & 28 & 9.3 \\
\hline
\end{tabular}

Note:

SPM/MCE/Senior Cambridge: Sijil Pelajaran

Malaysia/Malaysia Certificate Education

STPM/HSC: Sijil Tinggi Pelajaran Malaysia/High School

Certificate

CFA of overall measurement model (see Figure 1 in Appendix) shows that the comparative fit index (CFI) and the Tucker-Lewis index (TLI) performed at unacceptable level of values ( 0.836 and 0.846 respectively) although the root mean square error of approximation (RMSEA) has reached to an accepted value of 0.076. According to Hair et al. [30], the acceptable level of RMSEA must be lower than 0.08, CNI and TLI are more acceptable at value above than 0.90. Thus, to meet a good fitness of model as presented by the re-specified overall measurement model (see Figure 2 in Appendix) some items of transformational, trust and innovation constructs were omitted due to high value of errors found in Modification Indices of AMOS output. This re-specified model performed the acceptable level of RMSEA, CNI and TLI values which are $0.038,0.981$ and 0.977 respectively, while PNFI achieves 0.814 .

Through CFA also, the construct validity was proven which all items had high values of factor loadings (FL) (more than 0.5) as found in the re-specified overall measurement model (Hair, Anderson, Tatham \& Blacks, 2010). The construct validity was also accepted by deleting 4 items of endogenous construct when their errors showed high values of modification indices. The reliability test (RT) of all constructs showed their internal consistency based on the results of cronbach's alpha (transformational leadership $=0.97$; employees' trust $=0.91$; innovation $=0.85$ ) above 0.60 as the acceptable standard of reliability analysis [26] Hence, the validity and reliability of those statistical results proven that the measurement scales selected for this study were accepted as demonstrated in Table 2.

Table 2: Validity and Reliability Analyses for Measurement Scales

\begin{tabular}{llll}
\hline Measures & Items & FL & RT \\
\hline Transformational Leadership & 20 & 0.72 to & 0.97 \\
\hline Innovation & & 0.86 & 0.85 \\
& 10 & 0.76 to & 0.87 \\
\hline Trust & 12 & 0.68 to & 0.91 \\
\hline
\end{tabular}

Importantly, Table 3 presents the results of descriptive statistics from Statistical Package in Social Science (SPSS) and output of disattenuated correlation analysis generated from the AMOS. The means for the three studied variables are 3.80 (transformational leadership), 3.47 (trust) and 1.29 (innovation) which transformational leadership ranged at high moderate level. The correlation coefficients for the relationships between predictors (transformational leadership and trust) and criterion variable (innovation) show good relationships and proven discriminant validity.

Table 3: Disattenuated Correlation and Descriptive Statistics

\begin{tabular}{lllllll}
\multicolumn{1}{l}{ Variable } & Mean & STD & & & \\
\cline { 5 - 6 } & & & & Transformational Leadership & Trust & Innovation \\
\hline $\begin{array}{l}\text { Transformational } \\
\text { Leadership }\end{array}$ & 3.80 & 0.64 & 1 & 0.435 & 0.506 \\
\hline Trust & 3.47 & 0.47 & 0.435 & 1 & 0.857 \\
\hline Innovation & 1.49 & 0.26 & 0.506 & 1 & 1 \\
\hline
\end{tabular}

Note: STD=Standard Deviation

Results of direct and indirect effects relationship based on the existing of trust as shown in the hypothesized structural model (Figure 3) accepted H1, H2, H3 and H4. Those hypotheses status have been revealed by the significant effect of transformational leadership on employees' innovation $(\beta=0.165$, t value $=3.375$, $\mathrm{p}<0.05)$ and significant effect of transformational leadership on employees' trust $(\beta=0.435, \mathrm{t}$ value $=6.584, \mathrm{p}<0.05)$ as well as the significant effect of employees' trust on employees' innovation $(\beta=0.785, \mathrm{t}$ value $=10.323, \mathrm{p}<0.05$ ). This could be interpreted that the effective implementation of transformational leadership approaches by the leaders via inspirational motivation, individualized consideration and idealized influenced have indirectly promoted the practice of creative ideas and positive paradigm shift among the enforcement employees in LAs through employees' trust in organization. Employees who trust their transformational based leaders, systems and peers of organization are more motivated to be highly innovative. 


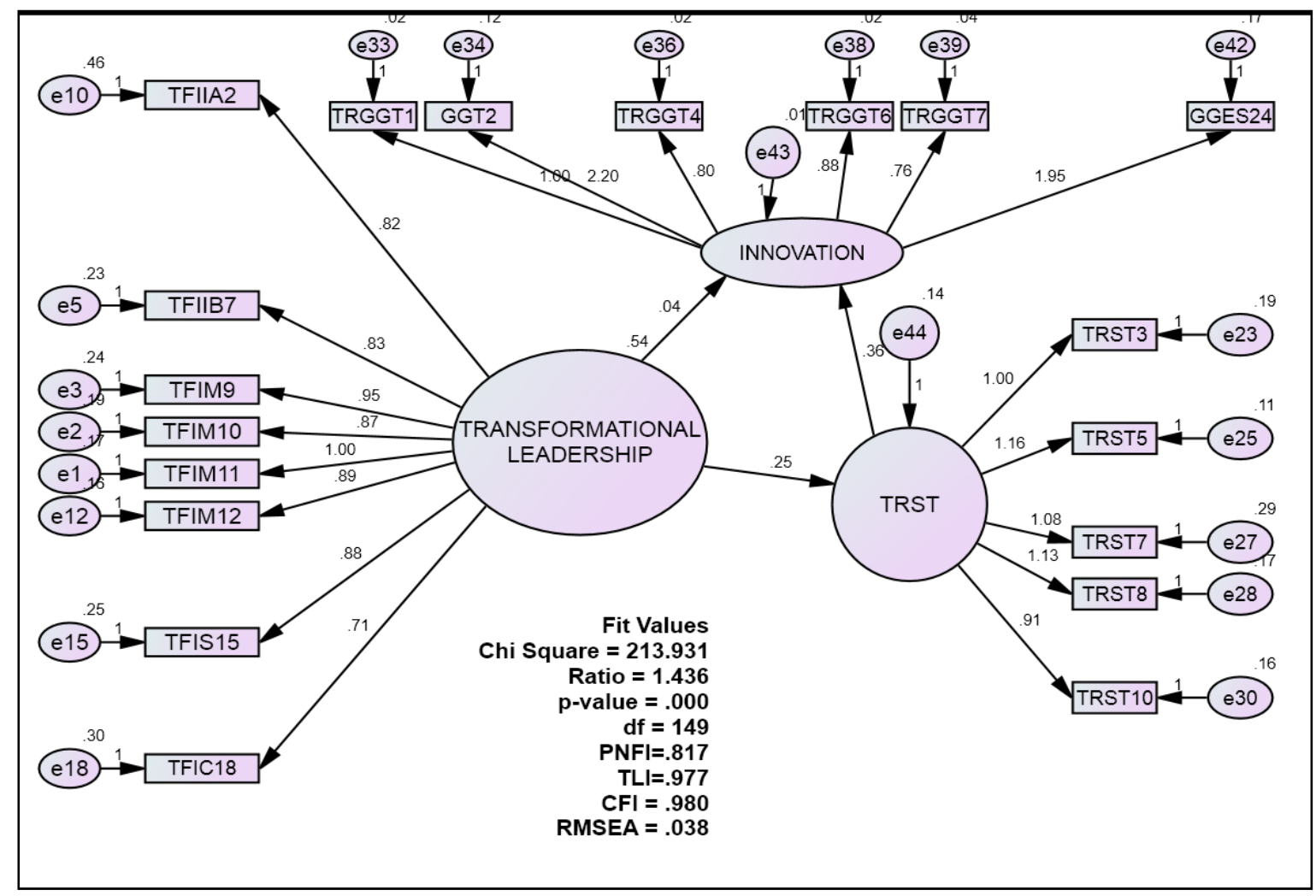

Fig. 3: Hypothesized Structural Model

\section{Discussions and Implications:}

The main objective of this study was to test the impact of transformational leadership on employees' innovation and whether this relationship has mediating effect of employees' trust from the perspective of enforcement industry. In general, the findings support the positive effect of transformational leadership on employees' trust and innovation. In other words, perceived behaviors of the transformational leaders by the employees increases their performance to be innovative. Such finding confirms the importance of transformational leadership in increasing the innovation of employees, mainly, when the management and guidance provided to them are perceived empowering and encouraging them to demonstrate their viable idea in implementing their innovative roles. Moreover, the employees will be motivated to increase their innovation when they have trust on their organizations particularly based on the capability, integrity and benevolence of the transformational leaders and support from their co-workers.

Further, it is assumed that the results of this study could also be affected by the intense public sector transformation program implemented in LAs which strongly emphasizes the leaders to behave based on transformational leadership style [32]. The government is highly confident and believed on the uniqueness of the transformational leadership style that able to generate employees' trust in organization thereby promoting innovation among them. Therefore, the findings of this study empirically support the government agenda especially pertaining the leadership and employees' innovation development. The findings were supported by previous researches $[4,33]$ although they were conducted in different settings and contexts.

\section{Conclusion:}

This study confirms that employees' trust mediates the relationship between transformational leadership and employees' innovation in the context of public sector enforcement industry. This result in line with the past researches and contributes to the leadership and innovation researches literature related to Western and Eastern organizational settings. Hence, trust by the enforcement employees becomes an important intervening determinant to develop innovation characteristic among them. This must be highly considered by the public sector organizations management in Malaysia that emphasizes transformational leadership. It is also useful for those who are interested in the same area of study of their future researches. As a result, this will help to increase the good governance practice among the enforcement employees and fighting themselves from misconduct especially corruption. Consequently, supporting the LAs in delivering quality of services to the public beside, they will be more trusted in future.

\section{REFERENCES}

[1] Jung, D.I., C. Chow and A. Wu, 2003. The Role of Transformational Leadership in Enhancing Organizational Innovation: Hypotheses and Some Preliminary Findings. Leadership Quarterly, 14(4-5): 525-544.

[2] Avolio, B.J. and F.J. Yammarino, 2002. Introduction, and overview of transformational and charismatic leadership. In: Avolio, B.J. and Yammarino, F.J. (Eds), Transformational and Charismatic Leadership: The Road Ahead. JAI Press, Amsterdam.

[3] Hunt, J.G. and J.A. Conger, 1999. From Where We Sit: An Assessment of Transformational and Charismatic Leadership Research. The Leadership Quarterly, 10( 3): 335-345.

[4] Paulsen, N., V.J. Callan, O. Ayoko and D. Saunders, 2013. Journal of Organizational Change Management, 26(3): 595-610.

[5] Mohd Sidek, H., 2007. Garispanduan Untuk Mempertingkatkan Tadbir Urus Dalam Sektor Awam. Jabatan Perdana Menteri, Putrajaya, Malaysia. www.mampu.gov.my/. Retrieved on $27^{\text {th }}$ March 2013.

[6] Siddiquee, N.A., 2008. Service Delivery Innovations and Governance: The Malaysian Experience. Journal of Transforming Government: People, Process and Policy, 2(3): 194-213.

[7] Amabile, T.M., R. Conti, H. Coon, J. Lazenby and M. Herron, 1996. Assessing the Work Environment for Creativity. Academy of Management Journal, 39 (5): 1154-1184.

[8] Belliveau JW, Kennedy DN, McKinstry RC, Buchbinder BR, Weisskoff R, Cohen MS, Vevea JM, Brady TJ, Rosen BR. Functional mapping of the human visual cortex by magnetic resonance imaging. Science. 1991 Nov 1;254(5032):716-9.

[9] Eisenbeiss, S.A., D. van Knippenberg and S. Boerner, 2008. Transformational Leadership and Team Innovation: Integrating Team Climate Principles, Journal of Applied Psychology, 93(6): 1438-1446.

[10] Bass, B.M., 1985. Leadership and Performance Beyond Expectations. Free Press New York, NY. 
Citation: Mohd Hamran Mohamad, Khulida Kirana Yahya and Kamarulzaman Lamin, 2018. Impact of Transformational Leadership on Innovation Characteristic of Enforcement Employees in Malaysian Public Sector Agency. The Role of Trust as Mediator. Advances in Natural and Applied Sciences., 12(3): 60-65.

[11] Bass, B. and B. Avolio, 1993. Transformational Leadership and Organizational Culture. Public Administration Quarterly, (17): 112-21.

[12] Burns, J., 1978. Leadership, Harper \& Row New York, NY.

[13] Bass, B.M. and R.E. Riggio, 2006. Transformational Leadership. Erlbaum, Mahwah, NJ.

[14] Hyypia, N. and S. Parjanen, 2013. Boosting Creativity With Transformational Leadership in Fuzzy Front-End Innovation Processes. Journal of Information, Knowledge and Management, 8: 21-41.

[15] Karimi, F. and Z. Morshedi, 2015. The Relationship Between Transformational Leadership With Organizational Innovation. International Journal of Educational and Psychological Researches, 1(3): 226-233.

[16] Fishbein, M. and I. Ajzen, 1975. Belief, Attitude, Intention, and Behavior : An Introduction To Theory and Research. Reading, Mass. Addison-Wesley Pub. Co. Don Mills, Ontario.

[17] Mayer, R., J. Davis and F.D. Schoorman, 1995. An Integrative Model of Organizational Trust. Academy of Management Review, $20: 709-734$.

[18] Kramer, R.M. and T.R. Taylor, 1995. Trust in Organizations: Frontiers of Theory and Research. Thousand Oaks, Calif. Sage.

[19] Ertürk, A., 2008. A Trust-Based Approach To Promote Employees' Openness To Organizational Change in Turkey. International Journal of Manpower, 29(5): 462-483.

[20] Rousseau, D., S.B. Sitkin, R.S. Burt and C. Camerer, 1998. Not So Different After All: A Cross-Discipline View Of Trust. Academy of Management Review, 23(3): 393-404.

[21] Sarros, J.C., B.K. Cooper, J.C. Santora, 2008. Building a Climate for Innovation Through Transformational Leadership and Organizational Culture. Journal of Leadership Organization Study, (15): 145-58.

[22] Azman, I., M. Mohd Hamran, A.M. Hasan, M.R. Nurhana and P.Z. Woon, 2010. Transformational and Transactional Leadership Styles as a Predictor of Individual Outcomes. Theoretical and Applied Economics, XVII(6): 89-104.

[23] Pillai, R., C.A. Scriesheim and E.S. Williams, 1999. Fairness Perceptions and Trust as Mediators for Transformational and Transactional Leadership: A Two-Sample Study. Journal of Management, 25(6): 897-933.

[24] Konovsky, M.A. and S.D. Pugh, 1994. Citizenship Behavior and Social Exchange. Academy of Management Journal, 37(37): 656-69.

[25] Krejcie, R.V. and D.W. Morgan, 1970. Determining Sample Sizes for Research Activities. Educational and Psychological Measurement, 30: 607-610.

[26] Sekaran, U. and R. Bougie, 2010. Research Method for Business. A Skill Building Approach (5th Ed. John Wiley, Chichester.

[27] Tsui, A.S., J.L. Pearce, L.W. Porter and A.M. Tripoli, 1997. Alternative Approaches to the Employee-Organization Relationship: Does Investment in Employees Pay Off? Academy of Management Journal, 40: 1089-121.

[28] Rogers, D.P., 1987. The Development of a Measure of Perceived Communication Openness. The Journal of Business Communication, 24(4): 53-61.

[29] Cook, J. and T. Wall, 1980. New Work Attitude Measures of Trust, Organizational Commitment and Personal Need Non Fulfillment. Journal of Organizational Psychology, 53: 39-52.

[30] Hair, J.F., R.E. Anderson, R.L. Tatham and W.C. Black, 2010. Multivariate Data Analysis. (5th Ed.). Prentice Hall International Inc. New Jersey.

[31] Zainudin, A., 2012. Structural Equation Modeling Using AMOS Graphic. University Publication Centre (UPENA), Universiti Teknologi MARA, Shah Alam, Selangor.

[32] Unit Pemodenan Tadbiran dan Perancangan Pengurusan Malaysia (MAMPU) 2014. Memacu Transformasi. Retreived from www.mampu.gov.my, 13th April 2016.

[33] Krog, C.L. and K. Govender, 2015. The Relationship Between Servant Leadership and Employee Empowerment, Commitment, Trust and Innovatie Behaviour: A Project Management Perspectie. Journal of Human Resource Management, 13(1): 1-12.

Appendix:

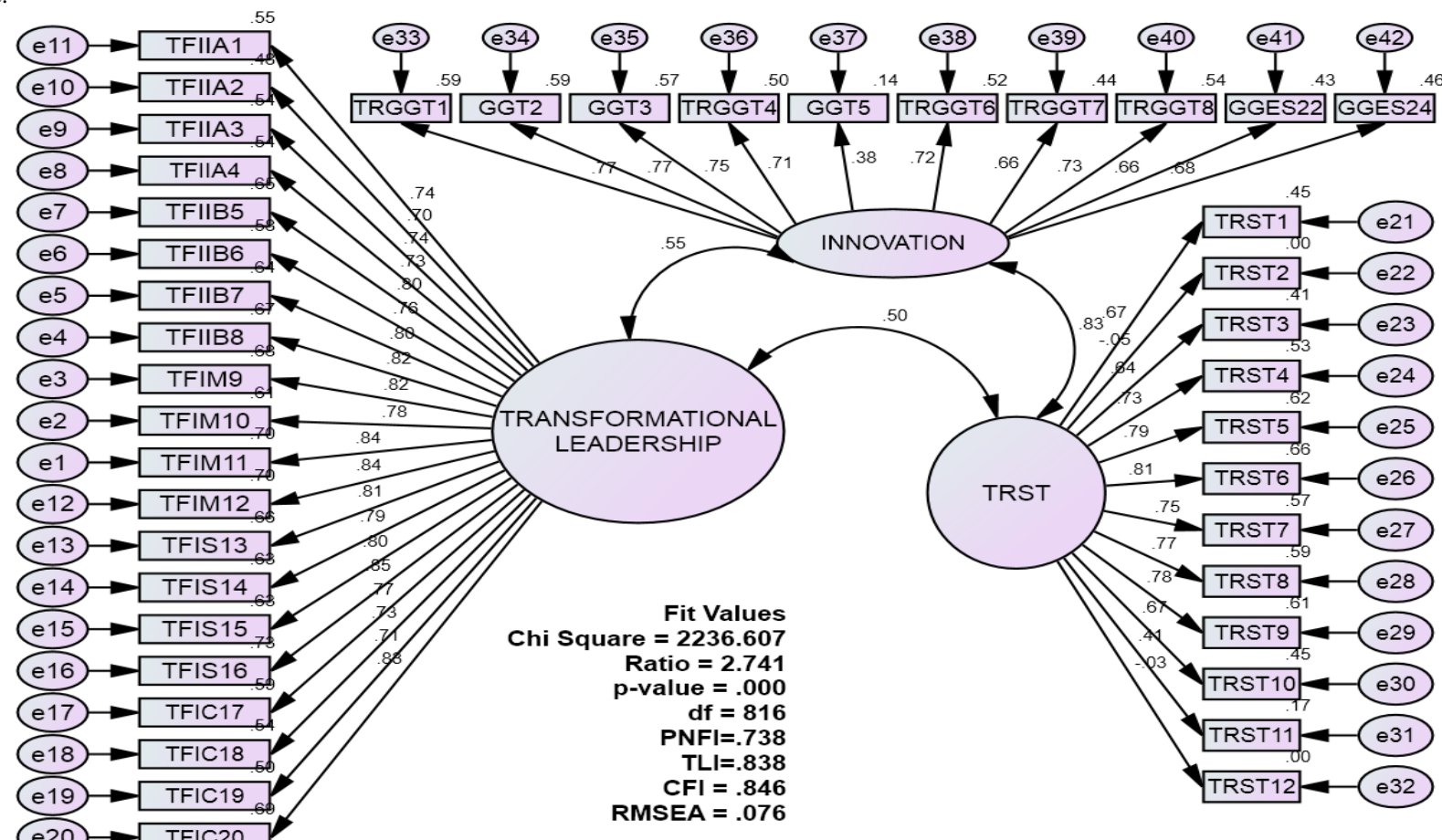

Fig. 1: Overall Measurement Model 


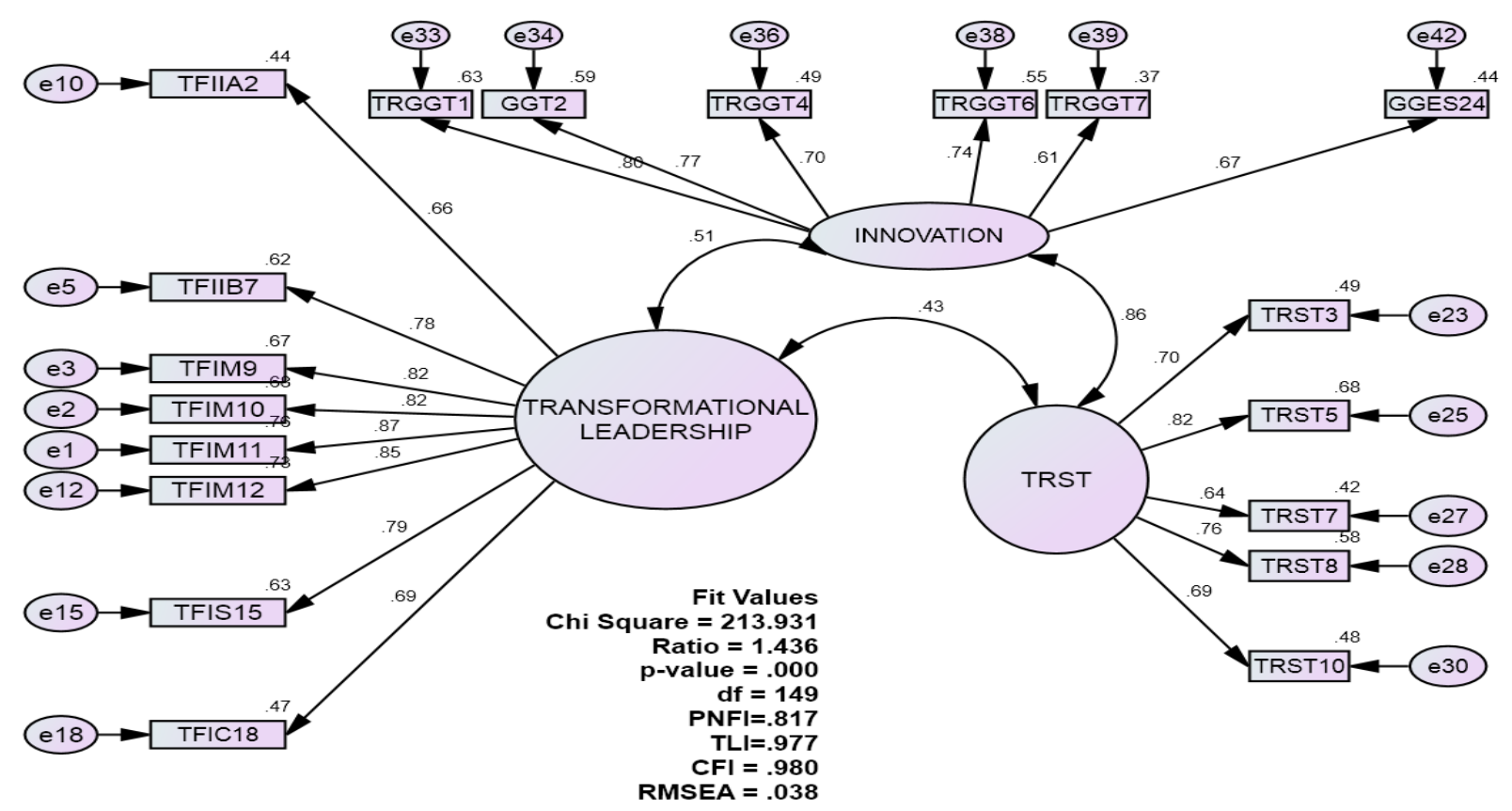

Fig. 2: Re-specified Overall Measurement Model

Correlations: (Group number 1 - Default model)

Correlations: (Group number 1 - Default model)
\begin{tabular}{|lll|c|}
\hline & & & Estimate \\
\hline TRANSFORMATIONAL_LEADERSHIP & $<-->$ & TRST & .435 \\
TRANSFORMATIONAL_LEADERSHIP & $<-->$ & INNOVATION & .506 \\
TRST & $<-->$ & INNOVATION & .857 \\
\hline
\end{tabular}

